\title{
THE CAREER OF JUDGES AND PROSECUTORS IN CONTINENTAL COUNTRIES MORRIS PLOSCOWE $\dagger$
}

$\mathrm{I}^{\mathrm{N}}$

$\mathrm{N}$ THE last analysis the crucial factor in the administration of criminal justice is the calibre of the individuals who man the organization and apply the procedure. Intelligent and honest effort may largely compensate for the shortcomings of chaotic organization and archaic procedure. But no procedural or administrative arrangements have yet been devised whose purpose cannot be ruined by incompetent, venal, or subservient officials in key positions. France with an admirable administrative and judicial organization produced a Stavisky scandal which shook the nation to its foundations. The lack of any structural unity in its system has not prevented England from producing a brand of judicial honesty which commands respect at home and abroad. The city of Milwaukee, with a procedure and organization differing in no essential respect from those in other American municipalities, is one of the few bright spots in the dreary picture of law enforcement in America because it has obtained consistently, over a period of years, honesty and intelligence in its courts and prosecuting offices. The means which are taken to secure honesty, capacity and independence on the bench and in the prosecutor's office are thus of vital importance.

America has largely abandoned the inherited practice of leaving the choice of the judiciary and prosecutors to the executive, in favor of poptlar election. That the attempt to place the election campaigns of these officials on a higher level than those of other elective officials has not been successful is evidenced by the fact that the periodic revelations of incompetency and corruption in office extend to the judicial and the prosecuting offices. When such scandals break, a cry goes up for a return to the English method. Traditionally, the English leave the appointment of judges to the executive authority and recruit them from men who have made a success at the bar. The private career of the appointee is sufficient test of his knowledge of the law. It is also an indication that he has had a wide variety of contacts from which he has probably acquired that breadth of knowledge, and familiarity with the social, economic, and financial currents of the day which are a valuable part of any judge's equipment.

The Continent approaches the problem of manning the magistracy (which includes the prosecutors) from quite another angle. In France, Germany, and Italy, the bar and the magistracy are two separate pro-

†Member of the New York Bar. 
fessions; and judges are trained for their functions in much the same manner that lawyers and doctors are trained for theirs. Following a university and legal education a young man's capacities for judicial or prosecutorial duties are tested by examination, and developed by apprenticeship. In contrast with the custom in England, where the executive is bound by a minimum of formalities and legal provisions in making his choice for any judicial post, the executive authority on the Continent must observe a complex set of provisions, designed to open the ranks of the judiciary to merit and close it to political influence. Once appointed, an English judge seldom looks upon his position as a stepping stone to a higher one. His appointment is usually the culmination of his career, whether appointed county judge or Lord Chief Justice of England. But on the Continent, since the magistracy is a career, the judges of the higher ranks are recruited from those of the lower, and these movements within the judiciary and the prosecutorial offices are, like entrance to it, hedged about with complicated regulations.

Certain factors in the judicial organization complicate judicial and prosecutorial careers in Europe. In the first place, in contrast to England and America, all courts in France, Germany, and Italy, except the petty courts, are collegial. The Europeans feel that the participation of several judges in a decision gives greater guarantee of its soundness. Trial courts of general jurisdiction function with three judges; appellate courts, with at least the same number. In the second place, European courts are sedentary. Neither France, Germany nor Italy follows the English practice of holding assizes by a limited number of circuit judges sent out from a central court at stated periods. To bring justice to the door of the litigant, large numbers of inferior courts and trial courts of general jurisdiction are provided. ${ }^{1}$ Even the limited number of appeal courts are regional so that the suitor has no great distance to travel. Only in those cases which come up before the supreme court of the land, must the litigant make the trip to the capital. Thirdly, none of these countries have an institution similar to the English justices of the peace, the non-professional unpaid laymen, who, with or without a jury, dispose of the bulk of criminal cases and permit a limited number of professional

1. A recent French decree attempts to cut down the number of judges required by the local trial courts of general jurisdiction. Instead of maintaining a full complement of at least three judges for each court as heretofore, it is now provided that only one judge shall be permanently stationed in specific courts which have little judicial busines. On the days when cases are to be tried, additional judges may be obtained from the neighboring court. See (1934) LES Lors Nodvences 331 et seq. A similar desire to reduce the number of judges necessary is evident in the recent decree cutting down the number of judges necessary for decisions in the Court of Appeal from five to three. Decree of June 25, 1934, (1934) Las LoIs Nouvetres 543-545. 
magistrates to judge the rest. In France, Germany and Italy a professional magistrate participates in the judgment of all cases from the pettiest offenses to the gravest crimes. Fourthly, qualified magistrates are required not only to perform judicial functions, but also to act as investigating magistrates and as prosecutors. In none of the three countries is there any difference in qualification or career between the prosecutors and the members of the judiciary.

The collegial and sedentary character of the courts, the lack of lay magistrates, the requirements of qualified judges as prosecutors, the extensiveness of their functions, and the need for investigating magistrates, make necessary for European judicial organization a more numerous personnel than is required by either the English or the American system. New York, a state of about 10,000,000 people, has about 450 paid judges. England, a country of about $40,000,000$ people, has about $175 .^{2}$ Germany, a country of $65,000,000$ people, has about 12,000 magistrates. ${ }^{a}$ France has a population of about $42,000,000$ and about 5,400 magistrates. ${ }^{4}$ Italy, with about the same population as France, has about 4,300 magistrates. ${ }^{5}$ A European country, then, has a small army of magistrates to recruit. Competent young men must be attracted to the judicial career to fill the lower posts. Many of them must be capable of developing sufficiently to be entrusted with the higher positions, which carry with them not only the responsibility for decisions in more important cases but also important administrative duties.

\section{The Recruiting and Training of Magistrates}

The most elaborate system of regulating the choice and training of candidates for the magistracy is found in Germany, where apprenticeship preceded and followed by success in examinations is necessary to qualify for appointment. To be eligible for the first examination the candidate must have completed a three year course of legal studies in a university. In Prussia the examination consists of a piece of legal research on some assigned subject to be completed within six weeks, four separate written examinations, and an oral examination covering most of the fields of the law.

If the candidate passes this series of examinations he is named a "Referendar." He must then serve an apprenticeship of three years designed to give him practical training in all the different branches of the

2. However, some of the functions performed by judges on the Continent, are performed in England by justices of the peace and by court clerks with a legal training.

3. Schiffer, Die Deutsche Justiz (1928) 113.

4. See (1931) AnNuare Statistique 81.

5. 1930 Raccolta Uffictale deile Legge II, 1621-1622.

6. Preussische Gerichtsverfassung (1926) 135 et seq. 
law. In Prussia the apprenticeship is divided into six periods of sis months each, passed as attachés to the inferior and superior courts and to the prosecuting attorney's office. One six months' period may, in the discretion of the "Referendar," be spent in a lawyer's or notary's (Notar) office. $^{7}$ The present regime has also added a number of months' service in a labor camp. If the "Referendar's" conduct is unsatisfactory or if he does not make sufficient progress in his work he may be disciplined or discharged from the service by the Minister of Justice. His work is unpaid, as a rule, but a limited number of "Referendare" who are in straitened circumstances and whose work is commendable may receive small sums for maintenance.

Upon the termination of his apprenticeship the "referendar" may peti. tion the president of the court of appeal (Oberlandesgerichtspräsident), for admission to the second examination (Grosse Staatsprüfung). The latter, upon satisfying himself that the applicant has completed his apprenticeship, may propose him, but the ultimate decision rests with the Minister of Justice. The examination, practical in character, intended to determine whether the candidate can be successfully entrusted with an independent post in the administration of justice, usually begins with a piece of legal research. ${ }^{8}$ The applicant is then compelled to work out a number of practical cases and he finally must undergo an oral examination. $\quad$ A candidate who fails may be reexamined only once and then only after a further period of apprenticeship. Successful candidates are named "Gerichtsassessoren."

Not all "Gerichtsassessoren" become judges. Many become lawyers; for admission to the bar requires success in the same examinations and the same apprenticeship as appointment to the judiciary. Others of the "Gerichtsassessoren" enter the public administrations, and some go into private undertakings. "Gerichtsassessoren" who wish to become judges are assigned by the Minister of Justice to an "Amtsgericht" or to a prosecuting attorney's office. Here, also, as during their apprenticeship, they are usually unpaid. But they may be named to posts as substitute judges in the lower courts (Hilfsrichter), or to temporary posts in the prosecuting attorney's office. In these cases the "Gerichtsassessor" is remunerated for the time that he actually renders service. In such temporary positions a "Gerichtsassessor" usually passes a number of years before he is finally named to his first permanent job in one of the lower courts or in a prosecuting attorney's office. Permanent judges who have been

7. See Schwister, Über den Stand der Ausbildung unserer jungen Jurislen (Deutcehland, 1932) 24 DEUTSCHE RICHTERzEITUNG 3-8.

8. In its place the candidate may present a piece of legal research completed during his apprenticeship.

9. Preussisceie Gerichtsverfassuitc (1926) 138. 
appointed in the last three years have served an average of six and one-half years as "Gerichtsassessoren."

Italy and France recruit their magistrates by methods similar to those used in Germany. ${ }^{10}$ To qualify as a magistrate success in examinations and apprenticeship is necessary. But neither in Italy nor in Fance are the conditions so rigorous or the preparation so thorough as in Germany. In Italy the candidate must have three years of legal studies at a university and pass a competitive written and oral examination prepared and marked by a commission of magistrates, lawyers and law professors named by the Minister of Justice. ${ }^{11}$ Normally the successful

10. In France and Italy petty court judges are not recruited by the same methods and do not form part of the same judicial hierarchy as the ordinary magistrates. They will not be considered in the above discussion. Formerly Italy, like Germany, opposed no barrier to the promotion of judges in the petty to the superior courts. A position in tho petty court (pretore) was the first stage in the judicial career. In 1930 a law changed this system, organizing the career of the petty judges on a difierent basis than the judges in the superior court, thus going back to a system which existed in Italy belore 1890. See law of April 17, 1930, n. 421 and observations on the prior system by former Minister of Justice Rocco in 1 Lavort Preparatort det Codice Penale e dex Codice di Procedura Penale (1928) 29. By the terms of this law a graduate in law may take a competitive examination for admission as a judge to the pretorial court. If successful in the examination, he is named "uditore," and must serve an apprenticeship in these courts. After six months of apprenticeship he may be named "uditore vice pretore" with full powers and is destined to supplement the pretore in the exercise of their functions. After eighteen months' apprenticeship, the candidate may be named "pretore aggiunto" if he passes a theoretical and practical examination. The "pretore aggiunto" may be nominated titulary pretore, after three years of service, on the basis of a judgment as to his merits given by a promotion commission (consiglio giudiziario) attached to the Court of Appeal. A "pretore" may after nineteen years' service be considered for promotion to the Court of Appeal. Such a promotion would make him a member of the superior magistracy.

The French distinction between the methods of recruiting the magistrates for the tribunaux de paix and for the courts of first instance and appellate courts goes back to the French Revolution. To be named juge de paix one must be at least twenty-seven years old, have a diploma attesting legal studies, (licencié en droit, bachelier ou capacitaire en droit), hảve worked two to three years in a barrister's, solicitor's or notary's office or have exercised public functions for three years, etc. If the candidate has not had any legal studies he still may be named a juge de paix if he was for ten years a maire or "adjoint" of a maire, or a "conseillier général," or member of a commercial tourt.

The candidates for juge de paix must take a professional examination although certain classes of candidates such as former magistrates, functionaries of the ministry of justice of at least twenty years' service, may be named directly without examination. 1 GLASSON and Tissier, Tratté de Procédure Ctvite (3d ed. 1925) 114-116.

11. The law which lays down the fundamental provisions for the judicial organization is Law of Dec. 30, 1923, n. 2786, (1923) Raccolta UfFictale delte Legce X, 8643. This law has been modified by a number of later laws and especially by Law of Dec. 30, 1926, n. 2219, 1927 Raccolta UfFiciale I, 88 et seq. and Law of April 17, 1930, n. 421 in 1930 Raccolta UfFictale II, 1616, Law of June 5, 1933, n. 557, 19 LEX (1933) 558 et seq.

An excellent Italian book on the magistracy is Prola-Casercx, la Madrstratura (1907); see also 2 Manzini, Trattato di Diritto Proccessuale Penale Italiano (1931) 134 et seq 
candidate, known as an "uditore," is expected to undergo a three-year apprenticeship as an attaché to various courts and to the prosecuting attorney's office. But the Italians permit the "uditore" to be appointed assistant judge (vice pretore) in a petty court after his first six months of apprenticeship. 12 If the "uditore" wishes an appointment to the superior courts, he must serve two years of his apprenticeship before taking the qualifying examination, for which he must have the approval of the Minister of Justice. In ranking candidates after the second examination, the examining board of seven high judges takes into account the grade attained in the first examination, scholarly work done during the apprenticeship period, the candidate's attitude towards judicial work, his capacities and his general deportment. On the last three points the candidate's superiors during his apprenticeship are consulted.

In the order of the rank they attain, successful candidates are appointed as associate judges (giudici aggiunti) in the trial courts of general jurisdiction as fast as posts become vacant. The "giudice aggiunto" has all the powers of a judge and is paid for his services. Nevertheless the time passed as "giudice aggiunto" is considered an experimental period during which the young magistrate may attain complete maturity. Thus, he is not irremovable during good behavior as are the titulary judges. A "giudice aggiunto" must exercise his functions for three years before he can be named titulary judge (giudice) or a King's prosecuting attorney (sostituto procuratore del $\mathrm{Re}$ ).

France was for a long time remiss in providing systematic methods of recruiting its magistrates. ${ }^{13}$ During the nineteenth century few qualifications were established for the judiciary. Candidates had to be French citizens, twenty-two years of age or over, of good character and morals, in possession of all civil and political rights, holders of a diploma in law, and with at least two years' practice at the bar. ${ }^{14}$ No examination was prescribed; no other apprenticeship was required than that which might be had from a career of two years at the bar.

In 1876 Dufaure, a celebrated Minister of Justice, established a system of competitive examinations and organized an apprenticeship for candidates to the magistracy, but his successors dropped this system only three years later despite its excellent results, because it interfered with a political selection of the magistracy. ${ }^{15}$ Not until 1908 did the French

12. Such a post carries with it a small salary. In any event the "uditore", aiter eighteen months' service, is entitled to six hundred lire a month (about $\$ 30.00$ in gold) for the rest of his apprenticeship period.

13. A description of present methods of recruiting magistrates will be found in Grssso: AND TISSIER, op. cit. supra note 10 , at 105 et seq.

14. Law of April 20, 1810, 1810 BULLETIN DES LoIs (IV ser.) pt. 12, 291.

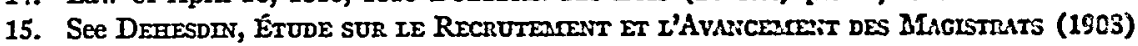
94 et seq. 
establish the existing system of recruiting. Admission to the judiciary is now by examination. In addition to the former qualifications, the candidate before admission to the examination must serve an apprenticeship of one year as an attaché to the Minister of Justice, or to a prosecuting attorney's office. ${ }^{16}$ The French are therefore not so rigorous in their requirements as either the Germans or the Italians. Only one examination is required, not two. The apprenticeship is shorter and does not provide so well-rounded an introduction into judicial functions.

Candidates desirous of taking the examination must address themselves to the Procureur de la République of the jurisdiction in which they reside, furnishing documents which establish their qualifications. These documents are transmitted to the Procureur Général of the appeal court in the district. The Procureur Général and the chief justice of the court make separate investigations of each candidate. They submit separate reports to the Minister of Justice, the original documents of the candidates being transmitted therewith. On the basis of these data and opinions, the Minister of Justice determines which candidates will be permitted to undergo the written and oral examinations designed to determine whether they possess the knowledge indispensable for the exercise of judicial functions. As a rule, successful candidates may only be named attachés to the Minister of Justice or substitute judges (juges suppléants) of the courts of first instance. ${ }^{17}$ However, the period which a candidate passes as a substitute judge, in contrast to the Italian practice, is not a prolongation of the apprenticeship; the "juge suppléant" is irremovable once he takes his oath of office.

All three countries make some exceptions to the usual methods of recruiting the magistracy. Least liberal is Germany. A lawyer may be named directly to exercise judicial functions, but this is hardly an exception, for lawyers have the same qualifications as candidates for the judiciary. The only actual exception to the ordinary rules is in favor of law professors, ${ }^{18}$ who may be named directly without examination and without apprenticeship. In Italy also, professors of law and lawyers who have practised ten years may be appointed directly to judicial functions. Before the appointment is made, the opinion of the superior council of the magistracy must be obtained; the candidates are then named to higher posts in the judiciary. In contrast to the Germans and Italians, the French make many exceptions to the normal methods of recruiting. One-sixth of all the vacancies in the magistracy in any one year may be filled by professors and lecturers in law faculties, members

16. Decree of May 11, 1934, (1934) Les LoIs Nouvelles 457.

17. Not more than six candidates who have especially distinguished themselves in the examinations may be named titulary judges on their first appointment.

18. Gerichtsverfassungsgesetz art. 4. 
of the Conseil d'Etat, lawyers, solicitors and notaries, certain categories of administrative officials, ${ }^{19}$ and so forth.

\section{Promotion}

Once initiated into the magistracy the young continental judge has ahead of him a well-defined hierarchy through whose various grades he may hope to advance to the top. Differences in rank carry with them differences in functions, in authority, in prestige, in dress and in salary. Appellate and trial court judges are differentiated in this manner. But procedure and administrative organization create demarcations in rank: within the same court. Every trial or appellate court has a chief judge responsible for all administrative matters. Judges of every large court are divided into sections, each of which has a chief. There are also striking differences in status between judges performing similar functions in different courts. Positions in courts located in large urban centers are more desirable than those in courts located in provincial towns. France and Italy therefore divide trial courts into three classes according to the importance of the town in which they are located. France also distinguishes between trial and appellate courts in the provinces and those in Paris.

Of necessity, if the magistracy is organized as a career, the higher ranks must be filled by the advancement of those in the lower. Young men must be induced to enter this career by the hope of being able progressively to better their position in life as they grow in experience and capabilities. But advancement is not a mechanical process. Not everybody can be promoted. The higher the rank, the fewer the positions within it. The higher the rank, the greater should be the ability of the men occupying it. But the prizes attached to these posts inspire the use of influence with the dispensing powers for the coveted possession. The almost universal desire for promotion, coupled with the comparatively few possibilities, places great power in the hands of those who control advancement. The promise of promotion may easily be used to obtain a judiciary subservient to the executive authority. The first ostensible purpose of regulating promotion is to rule out political influence. If promotion could be made on the basis of seniority alone there would be no room for politics. But there is no constant correlation between seniority and merit. Good justice requires that the more capable magistrates occupy the higher posts. Some discretion must be

19. These officials are the secretaries of the chief justice and the Procureur Gencral of the Cour de Cassation, functionaries in the Ministry of Justice who have the grade of "rédacteur," after ten years' exercise of their functions, court clerks (grefiers) who have a diploma in law and ten years' exercise of their functions, etc. See GLAsso: ET TIssnes, op. cit. supra note 10, at 108 . 
lodged somewhere for the purpose of perceiving and rewarding merit. But some regard must also be had for seniority so that every judge will have a reasonable prospect of a career. To curb the illegitimate, and to achieve some workable compromise between legitimate though often conflicting claims to promotion, all three European countries have passed, revised, and proposed anew, a multitude of statutory provisions.

Up to 1906 the Minister of Justice in France had complete discretion in the advancement of magistrates. ${ }^{20}$ This delivered the French judiciary completely into the hands of a political official. Advancement could usually be obtained only by enlisting the support of politicians and friends who would use their influence with the Minister of Justice. Clemenceau, despite his sojourn in America, advocated the election of judges as a remedy. Before the Chambre des Députés he gave a succinct description of the existing situation:

"What does the Minister of Justice do when he wishes to nominate a judge? He consults his office where he finds ... excellent recommendations from journalists, functionaries, deputies, senators, and even of magistrates who tend naturally to perpetuate the nepotism of their organization. A choice must be made from among these recommendations, but how choose, how determine? Such and such a one is the friend of such and such an influential man; one considers it necessary to reconcile this person, assure oneself of the support of that one; reward the services of such and such a person who recommends a relative or friend." 21

Two decrees, one in $1906^{22}$ and the other in $1908,{ }^{23}$ tried to give some guarantee to the judges by instituting promotion lists (tableaux d'avancement) from which advancements had to be made. But these decrees still left so large a discretion in the Minister of Justice that they did little to check the old evils of political nepotism. Subsequent laws and decrees and especially that of July $21,1927^{24}$ which is still in force, have been more successful. At the present time the various positions in the courts and in the prosecuting authorities are grouped in twelve different categories. A magistrate may be promoted only to a post in the category immediately above his own and then only if he has attained inscription on a tableau d'avancement after at least two years' service in his present position.

20. Age limits were, however, fixed for the various posts in the hierarchy as follows: 25 years of age for the judges in the tribunaux, the Procureurs de la République, substituts of the Procureur Général and the Avocat Général, 27 years for the judges in the cour d'appel, and 30 years for the president and vice presidents of the tribunal, cour d'appel and the Procureurs Généraux.

21. Cited by DeEESDIN, op. cit. supra note 15, at 108-109.

22. Decree of 18 August 1906, Denespin, op. cit. supra note 15 , at 476 et seq.

23. Decree of 13 February 1908, DEHESDIN, op. cit. supra note 15, at 494 et seq.

24. Decree of 21 July 1927, 1927 SIREY, LOIS ET ARRETS 1107-1108. 
The preparation of the tableau d'avancement is an extremely complicated process. Annually, the Chief Justice and the Procureur Général of every court of appeal send in to the Minister of Justice a list of magistrates in their jurisdiction whom they deem worthy of advancement, ranked in the order of merit. Attached to the list is a detailed report on every magistrate recommended. Up to half the number of magistrates in each category eligible for promotion may be listed. Magistrates not recommended, who believe themselves unduly neglected, may address a demand for inscription on the tableau to the Minister of Justice through the Chief Justice and the Procureur Général of their court, who transmit these demands along with their own opinions.

Upon the basis of these recommendations and demands for inscription, a Commission of ten composed of the Chief Justice, Procureur Général, four judges of the Cour de Cassation and the four directors of the Ministry of Justice, draws up the tableau d'avancement. Since the directors are immediate subordinates of the Minister of Justice, he exercises a great deal of influence in drafting the list. Formerly the Minister of Justice had considerable discretion in making the actual promotions, for he could choose any magistrate within a particular category, whose name appeared on the tableau. Thus a magistrate could find his name on the tableau every year and yet not receive promotion. The Minister's power has however been gradually reduced by various enactments. ${ }^{25}$ By a very recent decree, the Minister's authority in making promotions is limited to selecting one of three names submitted to him by an elective commission of judges. ${ }^{26}$ This commission submits to the Minister the names of three judges inscribed on the tableau, for every vacant post in the judicial hierarchy.

This system of appointment does not apply to judges of the Cour de Cassation, to the Chief Justice and Procureur Général of the Cour d'appel, nor to the presiding justice and Procureur de la République of the Paris court (Tribunal de la Seine). For these posts, except for the

25. The tableau d'avancement was formerly valid for only one year. Every candidate had to be reconsidered every year for inscription. Consequently, a magistrate could ha deemed worthy of promotion one year and not appear on the list the nest. The apparent injustice of this system won for the magistrate who has once been inscribed an automatic reinscription on the next year's list unless the promotion commission expressly decides otherwise. Formerly also, a magistrate could be inscribed year after year and still remain at the same post. This, too, brought such protest that it was finally arranged to place magistrates who have been inscribed on the tableau for the longest period at the top of each category and to reserve for them one fourth of the avalable posts. This ruling applied only to the first five ranks in the hierarchy. Decree of July 21, 1927, 1927 SrEx;, LOIS et ARRETs 1108, art. 18, 19.

26. This Commission consists of the Chief Justice of the Cour de Cassation and two judges elected by members of this court, and a Chief Justice of an appallate and of a trial court, elected by the judges attached to these courts. 
nominations to the Cour de Cassation, ${ }^{27}$ the discretion of the Minister of Justice is unlimited. His discretion is exercised however only after consultation with his colleagues in the cabinet, who always give very careful consideration to these appointments in view of their very great political importance. $^{28}$

The advancement of magistrates in France is therefore governed by the following conditions. First, a magistrate must spend a certain number of years in one post before he can be promoted to a higher one, and the extent to which he can advance at any one time is limited. Second, the esteem in which a magistrate is held by his chiefs is a significant factor in his advancement. Third, a magistrate cannot advance unless a promotion commission decides that he is worthy of promotion. Fourth, the Minister of Justice who formerly had a large discretion as to advancement is now limited to making his choice from three names presented to him. Finally, inscription on the tableau gives no right to promotion and a certain number of the most important posts are not governed by the ordinary rules.

The Italians use methods of promotion similar in many respects to the French, though the system as a whole is more complicated. As has been noted, after a man has successfully passed his second examination, he is named an associate judge (giudice aggiunto). He may then be promoted to a post as a titulary judge after three years if he is recommended by the judicial commission attached to the appeal court of his district. ${ }^{20}$ The recommendations for promotion are made as in France on the basis of information furnished by the superiors of the associate judge. An associate justice whom the Commission declares unworthy of promotion may take an appeal from the decision to the superior council of the magistracy, consisting of ten of the highest judges in Italy. If the Council affirms the commission's finding, the associate judge is dismissed from the service.

In contrast to the situation in France, no rules restrict the discretion of the Minister of Justice in making appointments to the trial courts, although the Italian, like the French, trial courts are differentiated into three classes according to their importance. Promotions to the appellate

27. Nominations to the Cour de Cassation can only be made from among the Premier Président, Procureur Général, Conseiller d'État, Président de Chambre or Avocat Général près de la Cour d'Appel of Paris, Président or Procureur de la République of the Paris court, director in the Ministry of Justice after five years' scrvice if a former magistrate, professors of law of at least ten years' service, or lawyers of the Conseil d'Etat or the Cour de Cassation of at least 20 years' practice, etc. Law of April 28, 1919, 1919 BUluEIIN DES LoIS 1263, art. 17 (4).

28. Sharp, The Frence Crum Service (1931) 349.

29. This commission consists of the chief justice, chief prosecutor and three associate judges of the court of appeal. 
courts, however, are minutely regulated.30 Every year a competition (concorso) is provided for four-tenths of the expected vacancies in the courts of appeal and for all of those in the Court of Cassation. To be eligible for the competition for an appeal court judgeship, a man must have had at least eighteen years' service and have received the favorable opinion of the Judicial Council of the Court of Appeal in his district. In the competition for the posts in the highest court of the land, the Court of Cassation, only judges of the appeal court with at least four years' service are eligible. Both for the appeal courts and the supreme court, the competition takes place on the basis of "titoli," scholarly works, decisions rendered, and other documents which are evidence of the candidate's fitness. In addition, the hierarchic superiors of the candidate are requested to give their opinions of his work and character. For these courts, therefore, the basis for decision on promotions is little difierent from the French. The competition is judged by the superior council of the magistracy. Successful candidates are ranked in the order of merit, and promotion by the Minister of Justice must usually follow in the order of ranking.

The other sis-tenths of the posts in the courts of appeal which become vacant in any one year are filled from promotion lists. These lists are compiled by the superior council of the magistracy, not annually as in France, but as the need arises. Seniority is a very important factor determining inscription on these lists. Only the 150 oldest judges in point of service can apply. Promotion usually follows in the order in which the candidates deemed worthy of advancement are ranked.

The highest posts in the Italian hierarchy, as in the French, are exempted from the ordinary rules. The chief justice and the presiding judges of the various branches of the Court of Cassation, the prosecutors attached to this court, and the chief justices of the various appellate courts are named to their posts by royal decree after deliberation of the Cabinet. These appointments must be made from judges of the Court of Cassation who have had at least three years of service in that court.

This provision indicates that the Italians like the French have been loath to eliminate entirely the influence of the executive authority in making promotions. And this conclusion is supported by other provisions which give the Minister of Justice a large discretion in the advancement of magistrates. Promotions from one class of trial courts to another lie wholly in his hands. Even promotions to the appeal courts need not always be made from the promotion lists in the order of rank; for the Minister of Justice, "where the special exigencies of the service

30. Law of June 5,1933, n. 557, "Norme per le promozione nella magistratura," 19 LEx (1933) 558. 
require it, may make departures from this ranking." ${ }^{11}$ The judge of the "special exigencies" which justify this step, however, is the Minister himself. Likewise the ratings of the commission which judges the competition are not final. They must be approved by the Minister of Justice. The law directs that he shall give his approval to the ratings unless there has been a violation of law in the selection. ${ }^{32}$ One would expect that the fact that the competition is judged by the highest judges in Italy would be sufficient guarantee of the legality of the proceedings. But the only judge of this violation is again the Minister, and it is clear that he can refuse to certify on this ground those magistrates who have incurred his disfavor.

Germany has no such complex of rules and methods to fetter the executive authority in the promotion of magistrates. The Minister of Justice is free to advance whatever judge he pleases to any position in the judicial hierarchy. In Württemberg and Bremen and a few other states the court in which a vacancy exists may propose a candidate, but the government is not bound by this recommendation. In the rest of Germany even this formality does not exist. No judge has a right to promotion nor is there a time limit during which a judge must occupy one post before he is eligible for another. A young "Amtsrichter" may" become the president of the Reichsgericht. Executive discretion in the promotion of judges, however, was controlled until recently by administrative usage. No young judge at the beginning of his career was appointed to a high position in the judicial hierarchy. He usually began as a modest "Amtsrichter" in some small court and there he remained for a number of years before he received his first promotion. From one to five years after his appointment he might be named as "Staatsanwalt" (prosecuting attorney) in some court. After about ten years of service he might become "Landgerichtsdirektor" (president of one of the sections of the Landgericht). He might later be promoted to the appellate court (Oberlandesgericht). The judges attached to this court were usually men over fifty years of age. But within recent years it has been possible for comparatively young men of requisite capacity to be appointed to this court. What effect the new political regime in Germany will have upon administrative usage remains to be seen.

Probably the comparative simplicity of the German arrangements for promotion is due to the salary schedules for judges. In France and Italy promotion to a higher post carries with it a greater salary. In Germany an ingenious system of salaries makes concessions to seniority. If, for instance, a judge has occupied one post for a certain number of years, he

31. Law of June 5, 1933, n. 557, $19 \mathrm{LEX}$ (1933) 558, art. 9.

32. Id. art. 4 (6). 
will then begin to receive compensation equal to the initial salary of a magistrate in the rank next above him. There is therefore less pressure upon the magistrate to seek the higher post in order to better his financial position.

\section{The Calibre of the Europcan Magistracy}

Despite the complicated systems of recruiting and promotion, the Europeans are not wholly satisfied with the quality of their magistracies. Scepticism as to their competency is commonly expressed, and there is open disbelief in their independence of the government. But there is generally implicit faith in their honesty. The Seabury revelations which indicated widespread venality among the judges of New York are unthinkable in connection with the magistracies of France, Germany and Italy. ${ }^{33}$ An undoubted factor in maintaining high standards of honesty is the surveillance and discipline of hierarchic superiors. Each magistrate is immediately answerable for his conduct to his superior and the motives behind his decisions cannot remain concealed. In each country, however, the magistracy has developed an "esprit de corps," a professional morality and set of traditions which is absorbed by the individual magistrate. Whatever the explanation, the fact seems to be uncontested that the magistracies of France, Germany and Italy, despite their other faults, possess the virtue of honesty, and that the public has confidence in their integrity.

The question of competency is a different matter. The public does not seem to feel that the judiciary is as competent as it is honest. The primary difficulty is the very large number of qualified judges required to man the European judicial organization. Under any conditions it would be difficult to obtain a sufficient number of competent individuals. The Germans seem to have had the least amount of difficulty, owing to the abnormal post war economic conditions which made the security of judicial posts attractive. But German writers emphasize, with Dr. Muller, that "a first class judiciary which has not alone a few outstanding personalities but whose entire membership consists of men of the highest calibre can not be obtained where the number of judges required is so great." ${ }^{\text {"34 }}$ Of the French difficulties, Lecat writes:

33. Schiffer in his excellent book, op. cit. stipra note 3 , at 11 , points out that after the war, there was a noticeable degeneration in the traditionally honest German bureaucracy. But the German judges were not included in this process despite the fact that the same causes were operative. Although the magistracy in Germany has been reproached with many things, nobody has dared to question its integrity. For Italy see G.uLirm, Serrrm Grunmict (1914) 431-432.

34. MUller, Autr und Stellung des Richters (1929) 11 et seq.; see also Adrcres, GrUNDIRTEN DURCHGRETFENDER JUSTIZREFORAT (1906) 35 et seq. 
"For many years the recruiting of magistrates has been very difficult and it has become almost impossible today (1927). At the last examination for the admission to the judicial career, 100 places were available but only 30 candidates presented themselves. The insufficiency of candidates for the magistracy has resulted in a lowering of the standards of the examination." 35

\section{In Italy the eminent judge D'Amelio states:}

"The problem of the magistracy today (1925) is the problem of recruiting. For some time the examinations for admission into the magistracy obtain insuffcient and sometimes mortifying results. The reports of the examining commission to the Ministry of Justice are full of disheartening data concerning the scarcity of the number of those taking the competitive examinations in relation to the number of posts available, the little or no preparation of the candidates, their insufficient knowledge of the most elementary principles of the law, the poorly written compositions presented, full of grammatical errors, the incertitude and perplexity of the answers in the oral examinations. These symptoms give the examining commission the impression that except for a few candidates, the choices have not been very happy ones, and that the greater part of the new magistrates are not destined to inject any new spiritual and moral energy into the old judicial organization."

If the judges were better paid, the Europeans could attract a better class of candidates. In Prussia the great mass of judges and prosecuting attorneys (slightly over 6,000) are paid from 4,400 to 8,400 marks $(\$ 1,100-\$ 2,100) .^{37}$ About 240 judges are paid from 6,200 to 12,600 marks $(\$ 1,550-\$ 3,150)$. Forty-two are paid 14,000 marks $(\$ 3,500)$ and fifteen judges are paid from 16,000 to 22,000 marks $(\$ 4,000-$ $\$ 5,050){ }^{38}$ In France the titulary judges of first, second, and third class are paid respectively at the rate of 22,000 francs $(\$ 880), 28,000$ francs $(\$ 1,120)$ and 35,000 francs $(\$ 1,400)$ annually. ${ }^{30}$ The judges of the Courts of Appeal are paid 47,000 francs $(\$ 1,880)$ annually in the

35. Lecat, La Réforme Judictarre De 1926 (1927) 135. Sharp, notes, op. cit. supra note 28, at 184-185, that the recruiting of the French judiciary has noticeably declined both in quantity and quality. During the eight year period 1919-1927, approximatcly 1000 vacancies occurred in the magistracy. To fill these posts only 936 candidates were forthcoming, and naturally not all of them passed the examination. From 40 to $80 \%$ passed at 16 examination sessions, but the average score attained was only 71 points or barely the minimum. In 1925, moreover, only $30 \%$ of the candidates held doctor's degrees.

36. 1 Lavori Preparatori dei Codice Penale e dei, Codice di Procedura Penale 246 (1928).

37. The dollar figures are on a gold basis.

38. These figures are for the year 1930 and are taken from HAUSHALT DER JUSTZzvERWALTUNG FÜR DAS RECHNUNGSJAER 1930 (Prussia 1930) 12-14. This inferior economic status of German magistrates is not merely the result of the war. Even before the war there were complaints of a "Subalternisierung" of the magistracy. Sec Abickrs, op. cit. supra note 34 , at 7-8 and $48-49$.

39. The salaries in the Paris courts are much higher than they are in the provinces. A titulary judge is there paid 52,000 francs $(\$ 2,080$.) annually. 
provinces and 62,000 francs $(\$ 2,480)$ in Paris. The salary range of Italian judges is from 17,400 lire (about $\$ 870$ ) for the lowest paid judge to 74,000 lire $(\$ 3,700)$ for the highest paid judge in the hierarchy. A New York municipal court judge receives a salary of $\$ 9,000$ a year; a Supreme Court judge of the United States receives $\$ 25,000$ a year. A judge in the English County Court is paid $£ 1,500$ annually $(\$ 7,500)$ and a High Court judge $£ 5,000$ annually $(\$ 25,000)$.

Another unattractive feature of the judicial career in the eyes of capable young candidates is the prospect of having to spend a lengthy period in small communities. All three countries have large numbers of courts in small communities with comparatively little judicial business, yet requiring a complete judicial personnel. Young magistrates begin their career in these unimportant posts, where their official duties are not enough to absorb their energies or further their education and where other means of intellectual development are lacking. Mortara wrote of Italy:

"The miserable conditions of the career of the inferior court judges (pretore) are due not alone to the small salaries but also to the conditions of the organization of the career which render impossible study and apprenticeship. Even the finest steel, if not used for a long time, grows rusty. Similarly, the most acute jurist left in a humble town where there is a possibility of becoming a moron in six months, cannot retain his faculties in all their fullness and freshness for many years and for the time when he will be called upon to use them in more worthy positions."240

In a similar vein, Schiffer complains that the German judges

"are far from the stream of life, excluded from the fountains of intellectual development. They may become very easily, without their fault, small and narrow at a time when in the confusion of opinions, struggle of parties, opposition of ideas . . . it is especially necessary that they perform their duties with clear views and wide conceptions."

French critics sing the same tune. ${ }^{42}$

The sine qua non of improvement in all three countries is a fundamental reform of the judicial organization which will permit a drastic reduction in the number of judges required. The magistracy must be better paid, and governmental budgetary difficulties will permit it, only if the number to be paid is materially reduced. Twelve thousand German judges cannot be remunerated at the rate at which a couple of hundred English judges are paid. Greater financial prizes would unquestionably per-

40. Cited by D'Axretio in 1 Lavort Preparatori dec Codice Penale 5 dec Codice ni Procedure Penale 247 (1928); see also, Garante, op. cit. suppo note 33, at 17-31; $442-443$.

41. SCEMFFER, op. cit. supra note 3 , at 117 .

42. Lmat, op. cit. supra note 35 , at 136. 
suade more energetic and intelligent men to choose a judicial career. But, in addition, better monetary returns would enable the judiciary to attract the experienced lawyers with large practices who furnish such excellent contributions to the English judiciary. At the present time, an experienced lawyer in France, Germany and Italy, rarely abandons his practice for a judicial post. ${ }^{43}$ Reduction in the number of judges might come about through the limitation of the small tribunals and concentration of the judges in larger centers, the substitution of the single judge for the judicial college, the substitution of ambulatory for sedentary tribunals, limitations in the number of appeals and simplification of the procedure. If some of these reforms could be brought about, they would ameliorate other unfavorable aspects of the judicial career.

Unfortunately the path of judicial reform is no easier in Europe than in America. Efforts to suppress the small courts and to concentrate the judges in a number of large centers encounter considerable resistance. France in 1926 actually did abolish the tribunal d'arrondissement, a reform which had been demanded for a long time. But in 1930 practically all these tribunals were reestablished on the insistence of the local communities. The loss of the courts had deprived them of a certain amount of business and prestige which they missed.

\section{Lack of Independence of the Continental Judiciary}

But neither increase in salaries nor reduction in numbers will eliminate the fundamental vice of European judicial organization, the subserviency of the judiciary. It does not appear from the history of the judiciary nor from the operation of present guarantees against executive interference in justice, that an honest attempt has ever been made to free the European judiciaries from dependence upon executive authority. It is obvious that the party in power is always under the temptation to keep the judiciary dependent. It is a powerful weapon for the punishment of enemies and the reward of friends.

In France the independence of the magistracy was to some extent assured under the "ancien régime" by the system of selling judicial offices and by the hereditary nature of these offices. For the king to have discharged the incumbent shortly after selling him the post, because of a dispute over a decision, might have hurt the market for those offices. Nevertheless, interference with justice and the discharge of judges were far from unknown. After the Revolution, in every regime the principle of independence of the magistracy was announced; in none was it re-

43. This is also due in part to the hostility of the career judges. An experienced lawyer of many years' practice can only be appointed to one of the better posts. But these aro the prizes for the career men. No bureaucracy likes to see an outsider carry off the prizcs. 
spected. Napoleon twice conducted wholesale dismissals of judges who dissatisfied him. With the return of the Bourbons the constitutional charter of 1814 promised a position for life to all judges appointed by the king. The provision thus applied only to the future; before it was made effective, the judiciary was swept clean of all opponents of the regime. "The magistracy which the Restoration recruited from among 'party members' became very soon the instrument of its vengeance and its hatreds," wrote Jeanvrot.41 The Constitution of the July Monarchy repeated the promise of the 1814 charter, but the magistrates had to take an oath of allegiance or resign from the service. Napoleon III eliminated 132 judges by fixing an age limit at which the Minister of Justice might retire them. The expedient of requiring an oath of allegiance to the Emperor and treating the failure to take it as equivalent to resignation, removed many others whose attitude might prove obstructive. Nor has the Third Republic respected the principle of independence. In 1883, as a result of a prolonged agitation against the judiciary, a law was passed reforming the judicial organization and permitting the government to eliminate 614 hostile magistrates.

In Germany, Frederick the Great interfered frequently in the administration of justice, not only reversing decisions rendered by his courts, but also discharging and punishing judges who displeased him. ${ }^{13}$ In the reactionary period during and immediately after the Napoleonic Wars, there were many more cases of executive interference with justice. One of the principal demands of the German liberal movement before 1848 was the establishment of legal guarantees for the independence of the judiciary. This was obtained by specific provisions in the constitutions of the German states during the first half of the nineteenth century. The Weimar Constitution likewise included guarantees of judicial independence to apply to all of Germany. ${ }^{47}$ But the present regime in Germany has gone back to the traditions of an earlier day. A dependent judiciary is helpful to the National Socialists in exterminating their party opponents. Not only have all judges been discharged who are unfortunate enough to have had a Jewish grandparent, but also all judges "who, according to their prior political activity, do not provide sufficient guarantees that they will work for the National States without reserve ("rückhaltlos für den Nationalen Staat eintreten können"). ${ }^{\text {ss }}$

44. Jeanvrot, La Mlagistrature (1882) 181.

45. For this history, see Jeanvrot, op. cit. supra note 44, at 159 et seq.; DemEsors, op. cit. supra note 15 , at 1 et seq.

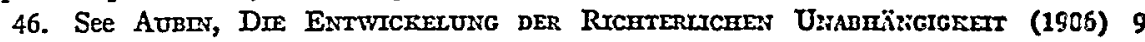
et seq.

47. Art. 102-104 of the Verfassung DES DEUTSCHEN RETCHS (1919).

48. GESETZ ZUR WIEDERHERSTELIUNG DES BERUTSBEA3rTENTUNSS, April 7, 1933, 34 RErcisGESETZBLATT 175. The only new judges who will be appointed in Germany in the future 
It is evident that no guarantees of independence are of any avail to the judiciary immediately after a revolution when political passions are most ruthless. Between revolutions, judges in France, Germany and Italy have had certain guarantees which made it possible for them to resist the undue pressure of the executive authority. The primary guarantee of a judge is a provision making him irremovable during good behavior. France accords this privilege from the moment a judge takes his onth of office. In Germany, however, it applies only to the titulary judges; ${ }^{40}$ the "Gerichtsassessor," even though he may exercise judicial functions, remains at the disposition of the government. In Italy, as in Germany, only the titulary magistrates (giudice) are irremovable, but even they must exercise their functions for three years before they are accorded this indispensable guarantee of independence. ${ }^{50}$ Ostensibly, this trial period gives the authorities opportunity to eliminate those who, in actual practice, prove unfit for judicial functions. But there is nothing to prevent interpreting as unfitness any sign of independence or any refusal to permit executive interference with justice.

In all three countries, a judge who has been accorded a life position cannot be deprived of his functions and salary or even temporarily suspended except when he reaches the retirement age fixed by law or after he is found guilty of breach of official duty by a special disciplinary court. In France and Germany this court is composed of the highest judges..$^{51}$ Italy has a unique court for this purpose; it is composed of six of the highest magistrates and six senators, ${ }^{52}$ named by royal decree. It is difficult to understand why senators are included unless it is to give the government great influence in disciplinary proceedings.

A position for life, within the limit of the retirement age, is not suffcient of itself to guarantee the independence of the judiciary. A judge

are those who have "the capacity to subordinate themselves willingly and frecly to National Socialist leadership." Kerrl, in 1934 DeUTSCHE JUSTIz 237-239. For the present it is the duty of every German judge to be a campaigner whose duty it is to take as the determining factor in his decisions the commands of the Führer. Freisler, in 1933 Prenssische Justiv, 383.

49. The very large use made of "assessors" in the German organization has been soverely criticized. It has been pointed out that this practise violates the guarantecs of an independent judiciary. The assessor is dependent upon the opinion of his superiors and upon the government for an appointment as a permanent judge. See KADE, DER DEUTSCuE RICHTER (1910) 73-74; AUBLN, op. cit. supra note 46, at 40.

50. Law of Dec. 30, 1923, 1923 Raccolta UfFiciale delle LeGGe X, art. 170.

51. The disciplinary court is, in Prussia, a special chamber of the Oberlandesgericht (Disciplinar Senat) or the Grosse Disciplinar Senat of the Kammergericht of Berlin; in France, it is the Court of Cassation.

52. The Senators must be named from among those who are neither lawyers nor former magistrates. Law of Dec. 30, 1923, 1923 Rnccolta UfFiciale detle LEcoe X, art. 189. 
must also be protected from arbitrary transference from one post to another. He cannot retain his independence if, as a result of a particular decision, he may suddenly be sent from a large center in which he has established himself and his family, to some isolated rural community. France, Germany and Italy provide that a judge may be transferred against his will only after the court competent in disciplinary cases renders a judicial decision. ${ }^{53}$

No less important for the question of independence is the manner in which assignments are made to the various branches of a court. If the assignment of judges is in the hands of the Minister of Justice, he is under the temptation of choosing judges favorable to his point of view to sit on cases in which he is interested. In Prussia in the 60's and in France under Napoleon III, when the Minister of Justice had this power, the government used it principally to obtain a favorable court to hear political cases. ${ }^{54}$ As a reaction to this situation, France and Germany have provided that the distribution of judges among the various chambers and among the various functions should be left in the hands of the judges themselves. In France every court makes this distribution annually through a commission composed of the president, the vice-president and the oldest judge, their plan being submitted to the entire tribunal for approval. ${ }^{55}$ Germany has a similar arrangement, except that the commission does not seek the concurrence of the rest of the court. ${ }^{\text {to }}$ Italy alone has still retained the decisive influence of the government in the distribution of cases and of judges. An annual royal decree sets forth the division of the courts into sections and the magistrates assigned to each. The same decree also designates which sections are to judge civil and which, criminal affairs. ${ }^{57}$

The guarantees for the independence of the judiciary which have just been examined, still leave open two avenues of influence and subserviency, namely the power of appointment and advancement. Although in appointing judges the Minister of Justice is generally restricted to those who have successfully passed the examination, he himself in all three countries, decides who will be permitted to take them. And the Minister has complete discretion to determine when the successful candidates shall be appointed titulary judges, if at all. The elaborate machinery set up to investigate the qualifications of every candidate before he is admitted

53. Glasson and Tisster, op. cit. supta note 10, at 124; Gerichtsverrassu:icscesetz art. 8; Law of Dec. 30, 1923, 1923 RAccolta UfFictare deche LegGe X, art. 170.

54. For Germany see SchmFER, op. cit. supra note 3, at 26-27; for France see BourCHardon, Le Migistrat (1926) 39-40.

55. GLASSON AND TISSIER, op. cit. supra note 10, at 205-206.

56. Gericintsuerfassungsgesetz art. 63, 64, 117, 131.

57. Law of Dec. 30, 1923, 1923 Raccolta Uffictace detre LecGe X, art. 33. 
to the examination, gives the Minister of Justice opportunity to determine, if he so desires, whether the candidate is pliable material or not.

But it is especially the power of advancement which is a menace to judicial independence. Examples to prove this assertion may be cited from every country. One illustration from French experience is typical. During the regime of Napoleon III, political offenses were tried by the 6th Chamber of the Paris Correctional Court. From 1859-1867, every judge who presided over this Court was elevated to the appellate court after only one year of service.

The elaborate rules and mathematical calculations making adjustments between merit and seniority, still leave considerable discretion in the Minister of Justice. Thus the latter may still use promotion as a prize for services rendered to the government. A German Minister of Justice, Leonhard, remarked that so long as he had the right of advancement in his hands, he was not concerned over the fact that judges were guaranteed a position for life and could not be transferred against their will. The ordinary judge does not wish to remain an "Assessor" or "Amtsrichter" all his life in a little village or in a God-forsaken small town. ${ }^{58}$ Jeanvrot wrote of France, "Thus magistrates, statesmen, publicists of all regimes and of all opinions agree in recognizing that a position for life (inamovibilité) but with the possibility of advancement, i.e., with a hierarchic system, is incapable of assuring the independence of the judges." is difficult for the individual judge to withstand not only the Minister of Justice but also his judicial superiors. As one prominent French politician states, "there is no practical or efficacious means of controlling the value of judgments made by the chiefs of a court upon their subordinates and of drawing up the 'tableau d'avancement.' It is therefore evident that the career of a magistrate depends upon his hierarchic chiefs. It is the decentralization of arbitrary power." indicates that judicial independence has an uneasy existence within a system of promotion. Galante observes that the judicial career is the cause of a continued agitation for promotions and for residences:

"There is nothing which disturbs the serenity of the magistrates more than the retardation of their promotions or the failure to satisfy their demands for transfer. ... The magistrates seek to obtain the desired position with the aid of deputies, friends of deputies, influential electors, or even of money. The magistrate may remain in this demoralizing state for years and the process begins anew with each new promotion and transfer."61

58. SCHIFFER, op. cit. supra note 3 , at 47 .

59. JEANYRot, op. cit. supra note 44, at 229. See also Bourchardon, op. cit. supra noto 54, at 31-45; DenESDIN, op. cit. supra note 15 , at 135 et seq.

60. De Monzie, Grandeur et Servitude Judictatre 48-49.

61. Gatante, op. cit. supro note 33 , at 434 ; see also Rocco in op. cit. supra note 10. 
But the most succinct statement of all comes from the German Adickes who observes, "It takes a long time before a judge has no more wishes to bring to a Minister."

Thus it is everywhere conceded that the prospect of promotion undermines the independence of the judiciary. When Napoleon introduced the hierarchy and the promotion system into the judiciary he was using the army as a model. By opening even the highest commands to soldiers of the humblest social standing who proved themselves worthy, the Little Corporal stimulated bravery, devotion to duty and all the other soldierly attributes in the rank and file. But merit in a soldier involves, among other things, unquestioning obedience to superiors. Decent judicial organization, on the other hand, requires that the individual magistrate be ready and able to act according to his own lights regardless of the opinions and desires of his superiors. Napoleon was probably aware of what he had done to his judicial organization. Like all dictators, he was not interested in having a judiciary in a position to oppose him. Unfortunately other continental governments which took the French judicial organization as a model were only slightly less anxious than Napoleon to preserve executive influence over the judiciary, although they may have paid lip service to the principle of judicial independence. A recent English student, comparing continental institutions to his own, concludes that the large measure of judicial independence obtained in England has been achieved "by divorcing almost all thought of promotion from the judge's career." He continues, "That feature has hitherto been too little remarked. It is, in truth, one of those happy and untheorized devices, stumbled on by a sort of horse-sense, in which English constitutional history has been so strangely and fascinatingly fertile."103

The complicated statutory regulations of promotion have unquestionably ameliorated the worst effects of the system. They cut down considerably the discretion of the Minister of Justice and make it possible for a capable magistrate to advance at some stage of his career without sacrificing his professional integrity for political favor. A wholly satisfactory solution to the promotion problem has not been found, not because it is beyond possibility, but because no European government has really wanted to find one. Politicians in Europe are as loath to lose their privileges as they are in America, and a dependent judiciary is a handy instrument. Though politics play a less admirable role in the European judicial organization than in the English, its part is nevertheless less objectionable than in America. What politics must be played

62. Adrckes, op. cit. supra note 34, at 40. See also Bunckmand, Des Rrenter (1909) 23 et seq.; KADE, op. cit. supra note 49 , at 82 et seq.

63. Ensor, Courts and Judges in France, Gerasant, Emglatid (1933) 43. 
in the European judiciary must be played on the level of national politics, and not on the level of ward politics as practised in America. Even if the continental judiciary is tainted with politics, the earlier selective processes have at least obtained a modicum of competence and professional training in its members.

To condemn the promotional aspect of the continental situation is not to condemn the whole idea of the judiciary as a career. The European conception is attractive in that it provides orderly methods of recruiting individuals for the performance of specified state functions. If it were feasible for the continental countries to reduce the number of judges to a bare minimum as in England, the English method of leaving appointment wholly to the executive, surrounding the judges with great social prestige, giving them salaries commensurate with their position, and selecting them from the ablest lawyers in private practise, might possibly be better than the existing system of careerism. But England herself pays a price for the excellencies of her small number of judges. She pays for it in the amateur work of the unpaid justices of the peace and in the expensiveness of litigation, occasioned in part by the fact that for some litigation in the first instance and for all appeals the suitor must go to the capitol. In the number of judges and the accessibility of courts, the United States is comparable to continental countries, but it would be rash to state that the appointive and the elective systems here produce better results than the career system on the continent. It has sometimes been questioned whether the career system can produce judges having as wide an outlook, as deep a culture, as great an understanding of social forces as the system of selecting for judgeship those who in their private work have had a large experience with men and with affairs. But it does not take much intimate contact with the French, German and Italian systems to realize that there are men on the bench in the higher courts of the three countries of whom any judiciary would be proud. Probably this question of development is an individual matter. If the Europeans provided more incentives for capable young men to enter upon the judicial career in the first instance and then organized the career in such a way as to permit a development of their faculties, they might obtain even better results than is the case at present. So far as the lower ranks of the judiciary are concerned, the European method of recruiting produces a type of magistrate who compares very favorably with inferior court judges in America and with the combination of untrained justice and legally trained clerk in England. Unlike the English lay justice, the continental inferior court judge has been trained in the law and in judicial functions under older men. Unlike the indispensable court clerk who assists the English lay justice, the continental inferior court judge assumes full responsibility for the exiercise 
of his powers and functions. His work is watched by men who know not less, but more law than he, and whose good opinion is important for his future career. After a study of continental courts and a comparison with the municipal courts in New York, the district courts of Massachusetts, and the reports on other inferior courts throughout the country, it is almost impossible to escape the conclusion that the European method of examination and apprenticeship is more successful in drafting competent and honest inferior court judges than is the American method of leaving the choice of magistrates to ward politicians. 